\title{
Integrating Livability Principles into Transit Planning: Screening Chicago Bus Rapid Transit Opportunities
}

\author{
Joshua K. Anderson, University of Chicago Office of Civic Engagement \\ Josh Ellis, Metropolitan Planning Council
}

\begin{abstract}
Pilot Chicago Bus Rapid Transit (BRT) routes proposed in 2008 were impractical to build, did not meet Institute for Transportation and Development Policy defined "gold standard" $B R T$, and were selected without considering the Livability Principles guiding investment by the U.S. government. Streets incompatible with BRT and not meeting basic constructability standards were eliminated. The remaining contiguous street sections were scored on the weighted performance of 14 quantitative proxies for the Livability Principles. Transit connectivity considerations further refined the pool to produce potential BRT routes. For discussion purposes, these routes were organized into a hypothetical BRT network to complement the existing rapid transit system; potential 2010 travel demand impacts were modeled. This study identified 10 potential BRT routes for further consideration. The integration of the Livability Principles into the study was promising but had limited impact because of the greater than anticipated influence of right-of-way width requirements.
\end{abstract}

\section{Introduction}

In 2008, the U.S. Department of Transportation (USDOT) chose four proposals submitted by the Chicago Transit Authority (CTA) as potential locations for a demonstration bus rapid transit (BRT) project (Chicago Transit Authority 2008). The four proposals had enhancements with elements similar to BRT, but were not "gold standard" BRT (i.e., dedicated bus lanes, at-grade boarding, pay-before-you-board stations, and signal-prioritized intersections) as defined by the Institute for Transportation and Development Policy (ITDP) prior to their establishment of the point-based "BRT Standard" in January 2012 (Weinstock et al. 2011; Institute for Transportation \& Development Policy 2013). The 2008 CTA proposal ultimately failed.

In 2009, the U.S. Environmental Protection Agency (USEPA), U.S. Department of Housing and Urban Development (USHUD), and USDOT formed an interagency collaboration, Partnership for Sustainable Communities, to better coordinate community investment. The Partnership was guided by six strategies - "Livability Principles" - that sought to bet- 
ter integrate the housing, transportation, environmental, and equity goals of the three agencies (U.S. Environmental Protection Agency 2009).

Following renewed interest in a BRT system in Chicago in 2011, this study was undertaken to assist decision makers in identifying BRT opportunities in Chicago and demonstrate that the Livability Principles could be quantitatively integrated into the transportation planning process. This was a screening study intended to produce, as Kittelson \& Associates (2003b, 2-2) noted, "alternatives for further refinement and/or analysis."

This study adhered to ITDP's characterization of the "gold standard" BRT as best practice; however, it is not the sole commentary on BRT (Weinstock et al. 2011). The variability of operational BRT systems is well-documented by the work of Levinson et al. (2003a), Wright and Hook (2007), Deng and Nelson (2011), and Weinstock et al. (2011)-some "gold standard" and some not. As of 2012, federal funding of 20 BRT systems in the United States had not been predicated on adherence to the gold standard (Government Accountability Office 2012). Subsequent to this study, the "BRT Standard" had both guided Chicago Department of Transportation's (CDOT) design efforts and provided funding opportunities for upcoming Chicago BRT routes (ITDP 2013; City of Chicago 2013). Moving Ahead for Progress in the 21st Century (MAP-21) revisions to 49 U.S.C. $\$ 5309$ divided BRT projects into fixed guideway (New Starts) and corridor-based (Small Starts) - definitions generally differentiated by the presence and absence, respectively, of "gold standard" required dedicated right-of-way (ROW).

At the time of this study, there was no explicit consideration of the Livability Principles in a transportation study; however, 49 U.S.C. \$5309(d) - under the Safe, Affordable, Flexible, Efficient Transportation Equity Act: A Legacy for Users (SAFETEA-LU) and, to a greater extent, MAP-21 had land use and economic development project justifications complementary to the spirit of the Livability Principles. The requirements of 49 U.SC. \$5309(d) (2008) had been reflected in the BRT transportation planning guidance provided by Kittelson \& Associates (2007). Some project sponsors of existing BRT systems in the United States had at least hoped for ancillary benefits beyond mobility improvements (Government Accountability Office 2012).

From 2009-2012, the Partnership for Sustainable Communities cited various examples of projects that aligned with the Livability Principles (Partnership for Sustainable Communities 2012). The Partnership also jointly reviewed the Federal Transit Administration (FTA) Alternative Analysis Planning Grant (49 U.S.C. $\$ 5339$ (2008)) under guidance of the Livability Principles. The alternative analysis, being a subsequent step to screening, was part of the impetus for this study; however, the program was repealed under MAP-21.

The literature lacked BRT screening studies, with the notable exceptions of research by McNamara et al. (2006) and the Center for Urban Transportation Research (2004) (the latter discussed later). McNamara et al. (2006) used a phased approach to select BRT routes from the existing Metropolitan Transportation Authority bus network. This study replicated that approach using four phases but differed in the metrics used to evaluate bus routes: 
- Phase I-Preliminary Route Screening eliminated routes not relevant to the study and consolidated routes with service overlap.

- Phase II-Segment Analysis was divided into two parts that established potential routes for BRT. First, the existing street network was evaluated to determine if the ROW was sufficient for BRT. Next, streets were evaluated on 14 criteria that attempted to broadly assess existing transit demand and complementary land uses in the surrounding areas. This section is congruent with, albeit prematurely in a screening study, Kittelson \& Associates' (2007) recommendation for consideration of ridership, travel times, constructability, and land development for a BRT alternatives analysis. In their statistical analysis of 46 BRT systems, Hensher and Li (2012) found transit connectivity to be "crucial" to BRT ridership. Mobility improvements were also requirements of 49 U.SC. $\$ 5309$ under SAFETEA-LU and MAP-21.

- Phase III-Route Analysis evaluated the integration of each route with the existing rail network and reintroduced or modified potential to improve transit connectivity.

- Phase IV-Travel Demand Analysis applied a travel demand model to the routes that passed Phase III to illustrate the impacts of a hypothetical BRT system.

This study was not a comment on the efficacy of BRT in the Chicago area over other forms of transit. Recommendations are based on existing conditions rather than potential benefits from a BRT route or system. The final grouping of recommended routes will require additional analysis, which is beyond the scope of this study.

\section{Methodology}

\section{Phase I: Preliminary Screening}

All CTA bus routes in service in October 2009 (155 routes) were examined using a twopart analysis consisting of consolidation and elimination. The system (see Figure 1) was chosen because it has a demonstrated demand for public transit.

First, two or more routes with only small deviations in alignment were consolidated into a single route. Next, three types of routes were eliminated from further analysis-Lake Shore Drive segments of some routes, downtown circulators, and special routes (seasonal, temporary, or short-run feeder routes).

This study did not deny the potential for enhanced transit along Lake Shore Drive; however, its purpose was to identify a small number of arterial routes that could provide maximum community benefits rather than identifying the robust system of supporting routes that Lake Shore Drive would require.

\section{Phase II: Segment Analysis}

The purpose of the segment analysis was to establish routes based on ROW constructability (Part 1) and access, transit performance, transit equity, and infill development potential (Part 2) scaled at a street-segment level. The extents of a street segment are defined by intersections with other streets as shown in Figure 2 . 


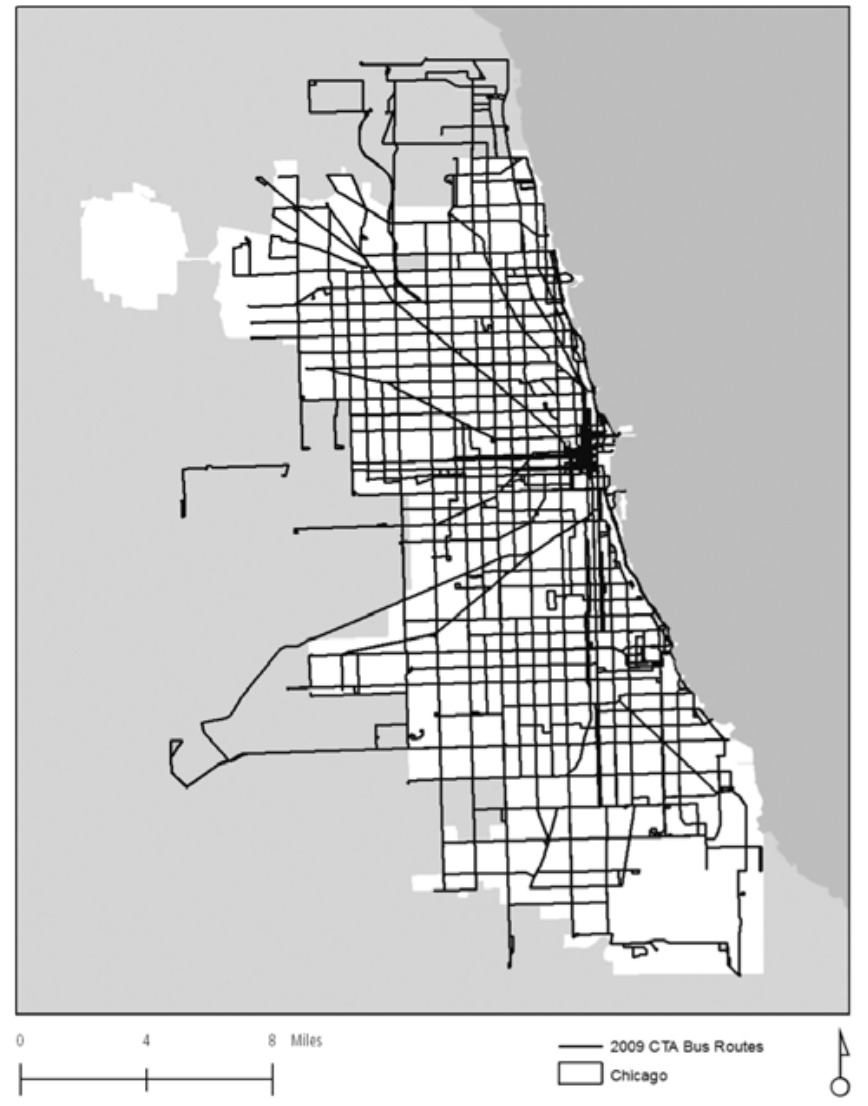

FIGURE 1.

Map of 2009 CTA bus routes

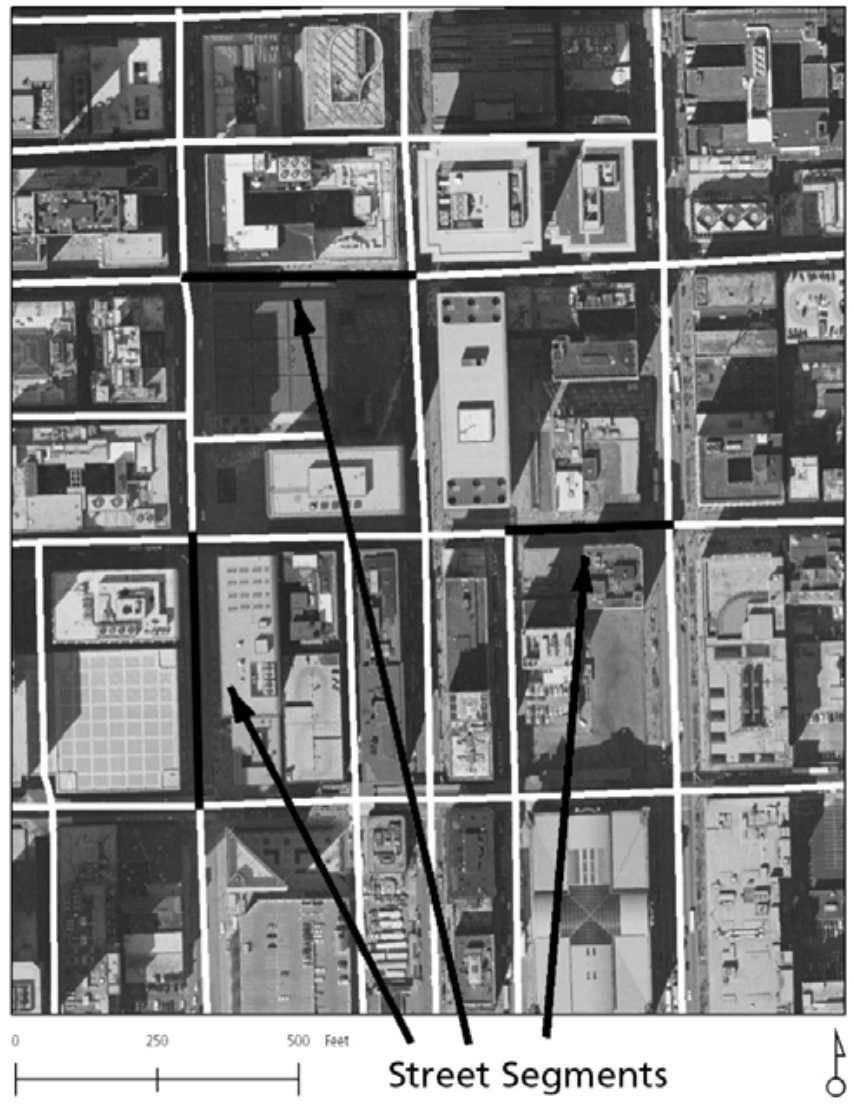

FIGURE 2.

Street segments

\section{Part 1: Right-of-Way Constructability Analysis}

The purpose of the ROW Constructability Analysis was to determine if sufficient public ROW width was available for a bi-directional BRT system along the street segments that passed Phase I.

- Step 1: Establish absolute minimum ROW width. Used for this study were minimum ROW widths recommended by the Institute of Transportation Engineers (2010) and Levinson et al. (2003b) for frontage zones; pedestrian travel ways; edge and furnishing strips; through, parking, bike, and BRT lanes; medians; and BRT stations. Based on those recommended minimum dimensions, two BRT standard minimum dimension scenarios were selected - a street segment with a BRT station (97 feet, $29.2 \mathrm{~m}$ ) and a street segment without a BRT station ( $86 \mathrm{feet}, 26.2 \mathrm{~m}$ ).

- Step 2: Assign ROW width to each street segment. Each street segment provided by CDOT came coded with ROW width information. Street segments outside the city, provided by the Illinois Department of Transportation (IDOT), did not have ROW width information; therefore, those street segments were coded by measuring the distance between parallel property lines using GIS. 
- Step 3: Designate street segments to be removed. Street segments not meeting the 86 -foot $(26.2 \mathrm{~m})$ minimum ROW width were identified but not immediately removed. In some instances, a street segment represented a short narrowing of street ROW width, such as occurs at a railroad viaduct. These segments were not deleted if preceded and followed by at least 0.25 miles $(0.4 \mathrm{~km})$ of suitable ROW. Based on recommended station distributions from 0.25 miles $(0.4 \mathrm{~km})$ to 2 miles (3.2 km) apart (Levinson et al. 2003b), at least 0.25 miles $(0.4 \mathrm{~km})$ of suitable ROW flanking a narrow street segment indicated the potential for a station and warranted the inclusion of a narrow street segment.

- Step 4: Establish minimum route length. A BRT route requires a series of street segments wide and long enough for operations. Although information was available on establishing maximum BRT route lengths, the literature did not contain sufficient rationale to establish a minimum route length. Instead, the average length (3-miles, $4.8 \mathrm{~km}$ ) of the four proposals submitted to USDOT in 2008 by CTA was used as an absolute minimum route length. Detailed modeling in future phases of subsequent studies would eliminate any impractical routes.

- Step 5: Remove Unsuitable Segments. Street segments less than 3 miles $(4.8 \mathrm{~km})$ in length were removed from the analysis. The remaining series of street segments required an adequate distribution of $97-$ foot $(29.6 \mathrm{~m})$ ROW widths to accommodate stations. A 0.5-mile station frequency distribution was selected based on recommendations for arterials by Kittelson \& Associates (2007). Any series of street segments that did not have a distribution of $97-$ foot $(29.6 \mathrm{~m})$ ROW widths at least 0.5 miles $(0.8 \mathrm{~km})$ apart were removed from the analysis. If a terminating series of street segments did not have at least one segment of $97-$ foot $(29.6 \mathrm{~m})$ ROW at its terminating end (allowing for a station), the entire terminus was removed. If the removal of any street segments caused a series of street segments to be less than 3 miles $(4.8 \mathrm{~km})$ in length, the entire series was removed from the analysis. The remaining street segments were advanced to the Livability Analysis.

\section{Part 2: Livability Analysis}

The purpose of the Livability Analysis was to provide a holistic approach to the transit screening process. Using 14 criteria-proxies for the Livability Principles (see Table 1) this analysis created a score for every street segment in the study area, which allowed a segment-by-segment analysis.

The method was similar to research by the Center for Urban Transportation Research (2004), which used four main criteria to quantify the propensity for successful BRT implementation in Miami-Dade based on existing conditions: 1) total average weekday existing bus ridership normalized by route length; 2 ) population and employment within 0.5 miles $(0.8 \mathrm{~km})$ of each route normalized by mile; 3 ) households with zero automobile ownership; and 4) households below $\$ 15,000$ in annual income. 


\section{TABLE 1.}

\section{Livability Analysis Criteria}

\begin{tabular}{|c|c|c|c|}
\hline Criterion & Study Measure & Rationale for Selection & Corresponding Livability Principles \\
\hline $\begin{array}{l}\text { Connectivity } \\
\text { to Community } \\
\text { Services }\end{array}$ & $\begin{array}{l}\text { Number of community destinations } \\
\text { within } 0.5 \text { miles }(0.8 \mathrm{~km}) \text { of street } \\
\text { segments }\end{array}$ & $\begin{array}{l}\text { People need transit access to vital } \\
\text { community services such as day care, } \\
\text { vocational rehabilitation centers, and } \\
\text { services for older adults. }\end{array}$ & $\begin{array}{l}\text { - Provide more transportation choices. } \\
\text { - Enhance economic competitiveness. } \\
\text { - Support existing communities. } \\
\text { - Value communities and } \\
\text { neighborhoods. }\end{array}$ \\
\hline $\begin{array}{l}\text { Connectivity } \\
\text { to Educational } \\
\text { Institutions }\end{array}$ & $\begin{array}{l}\text { Number of high schools, post-secondary } \\
\text { educational institutions, and libraries } \\
\text { within } 0.5 \text { miles }(0.8 \mathrm{~km}) \text { of street } \\
\text { segments. }\end{array}$ & $\begin{array}{l}\text { People of all ages need transit access } \\
\text { to educational opportunities such as } \\
\text { high schools, community colleges, and } \\
\text { libraries. }\end{array}$ & $\begin{array}{l}\text { - Provide more transportation choices. } \\
\text { - Enhance economic competitiveness. } \\
\text { - Support existing communities. } \\
\text { - Value communities and } \\
\text { neighborhoods. }\end{array}$ \\
\hline $\begin{array}{l}\text { Connectivity } \\
\text { to } \\
\text { Entertainment } \\
\text { Venues }\end{array}$ & $\begin{array}{l}\text { Number of cinemas, convention } \\
\text { centers, landmarks, museums, } \\
\text { performing arts centers, stadiums, and } \\
\text { zoos (within } 0.5 \text { miles }(0.8 \mathrm{~km}) \text { of street } \\
\text { segments. }\end{array}$ & $\begin{array}{l}\text { Transit access to cultural, entertainment, } \\
\text { and social destinations, (e.g., movie } \\
\text { theaters and museums) is a major } \\
\text { quality-of-life benefit for many people. }\end{array}$ & $\begin{array}{l}\text { - Provide more transportation choices. } \\
\text { - Enhance economic competitiveness. } \\
\text { - Support existing communities. } \\
\text { - Value communities and } \\
\text { neighborhoods. }\end{array}$ \\
\hline $\begin{array}{l}\text { Connectivity } \\
\text { to Food Stores }\end{array}$ & $\begin{array}{l}\text { Total annual sales of food stores within } \\
0.5 \text { miles }(0.8 \mathrm{~km}) \text { of street segments. }\end{array}$ & $\begin{array}{l}\text { People need transit access to fresh food } \\
\text { at grocery stores, produce markets, and } \\
\text { other types of food stores. }\end{array}$ & $\begin{array}{l}\text { - Provide more transportation choices. } \\
\text { - Enhance economic competitiveness. } \\
\text { - Support existing communities. } \\
\text { - Value communities and } \\
\text { neighborhoods. }\end{array}$ \\
\hline $\begin{array}{l}\text { Connectivity } \\
\text { to Major } \\
\text { Medical Care }\end{array}$ & $\begin{array}{l}\text { Number of hospitals within } 0.5 \text { miles } \\
(0.8 \mathrm{~km}) \text { of street segments. }\end{array}$ & $\begin{array}{l}\text { Patients and visitors need transit } \\
\text { access to critical medical care at major } \\
\text { hospitals. }\end{array}$ & $\begin{array}{l}\text { - Provide more transportation choices. } \\
\text { - Enhance economic competitiveness. } \\
\text { - Support existing communities. } \\
\text { - Value communities and } \\
\text { neighborhoods. }\end{array}$ \\
\hline $\begin{array}{l}\text { Connectivity } \\
\text { to Major Open } \\
\text { Space }\end{array}$ & $\begin{array}{l}\text { Number of community level parks- } \\
\text { defined by the Chicago Metropolitan } \\
\text { Agency for Planning (2008) as being } \\
\text { over } 25 \text { acres ( } 10.1 \text { hectares) - and forest } \\
\text { preserves within } 0.5 \text { miles }(0.8 \mathrm{~km}) \text { of } \\
\text { street segments. }\end{array}$ & $\begin{array}{l}\text { Transit access to recreational } \\
\text { destinations can improve usage rates } \\
\text { and health. }\end{array}$ & $\begin{array}{l}\text { - Provide more transportation choices. } \\
\text { - Enhance economic competitiveness. } \\
\text { - Support existing communities. } \\
\text { - Value communities and } \\
\text { neighborhoods. }\end{array}$ \\
\hline $\begin{array}{l}\text { Connectivity } \\
\text { to Retail }\end{array}$ & $\begin{array}{l}\text { Total annual retail sales at pedestrian- } \\
\text { oriented businesses within } 0.5 \text { miles ( } 0.8 \\
\mathrm{~km} \text { ) of street segments. Automobile- } \\
\text { related businesses such as gas stations } \\
\text { and auto dealerships were omitted. }\end{array}$ & $\begin{array}{l}\text { People require transit access to retail } \\
\text { opportunities to meet their shopping } \\
\text { and socialization needs. }\end{array}$ & $\begin{array}{l}\text { - Provide more transportation choices. } \\
\text { - Enhance economic competitiveness. } \\
\text { - Support existing communities. } \\
\text { - Value communities and } \\
\text { neighborhoods. }\end{array}$ \\
\hline $\begin{array}{l}\text { Employment/ } \\
\text { Job Access }\end{array}$ & $\begin{array}{l}\text { Total employment at all businesses } \\
\text { within } 0.5 \text { miles }(0.8 \mathrm{~km}) \text { of street } \\
\text { segments. }\end{array}$ & $\begin{array}{l}\text { Employees working in close proximity to } \\
\text { BRT lines are a major group of potential } \\
\text { riders, and BRT would increase their } \\
\text { ability to live and work near transit. }\end{array}$ & $\begin{array}{l}\text { - Provide more transportation choices. } \\
\text { - Enhance economic competitiveness. } \\
\text { - Support existing communities. } \\
\text { - Value communities and } \\
\text { neighborhoods. }\end{array}$ \\
\hline $\begin{array}{l}\text { Existing Transit } \\
\text { Ridership }\end{array}$ & $\begin{array}{l}\text { Average passenger flow by street } \\
\text { segment (controlling for direction) } \\
\text { during the AM peak period. }\end{array}$ & $\begin{array}{l}\text { Bus ridership demonstrates existing } \\
\text { demand for transit along the study } \\
\text { routes. }\end{array}$ & - Provide more transportation choices. \\
\hline $\begin{array}{l}\text { Existing Transit } \\
\text { Travel Time }\end{array}$ & $\begin{array}{l}\text { Average passenger speed by street } \\
\text { segment (controlling for direction) } \\
\text { during the AM peak period. }\end{array}$ & $\begin{array}{l}\text { Travel time reduction for passengers is a } \\
\text { main function of BRT. It is important to } \\
\text { identify routes where this benefit will be } \\
\text { maximized. }\end{array}$ & - Provide more transportation choices. \\
\hline
\end{tabular}




\begin{tabular}{|c|c|c|c|}
\hline Criterion & Study Measure & Rationale for Selection & Corresponding Livability Principles \\
\hline $\begin{array}{l}\text { Infill } \\
\text { Development } \\
\text { Potential }\end{array}$ & $\begin{array}{l}\text { Area of properties with potential for } \\
\text { redevelopment (defined by the CMAP) } \\
\text { and vacant properties within } 0.5 \text { miles } \\
(0.8 \mathrm{~km}) \text { of street segments. }\end{array}$ & $\begin{array}{l}\text { BRT can help infill development by } \\
\text { increasing underlying property values, } \\
\text { building station-area identity, and } \\
\text { growing pedestrian activity. }\end{array}$ & $\begin{array}{l}\text { - Provide more transportation choices. } \\
\text { - Promote equitable, affordable } \\
\text { housing. } \\
\text { - Enhance economic competitiveness. } \\
\text { - Support existing communities. } \\
\text { - Value communities and } \\
\text { neighborhoods. }\end{array}$ \\
\hline Population & $\begin{array}{l}\text { Total residential population within } 0.5 \\
\text { miles }(0.8 \mathrm{~km}) \text { of street segments. }\end{array}$ & $\begin{array}{l}\text { Residents living in close proximity to } \\
\text { BRT lines are a major group of potential } \\
\text { riders. }\end{array}$ & $\begin{array}{l}\text { - Provide more transportation choices. } \\
\text { - Support existing communities. } \\
\text { - Value communities and } \\
\text { neighborhoods. }\end{array}$ \\
\hline $\begin{array}{l}\text { Population } 0.5 \\
\text { Miles or More } \\
\text { from Rail }\end{array}$ & $\begin{array}{l}\text { Residential population within } 0.5 \text { miles } \\
(0.8 \mathrm{~km}) \text { of street segments who also } \\
\text { live beyond a } 0.5 \text {-mile }(0.8 \mathrm{~km}) \text { radius } \\
\text { of fixed guideway transit (CTA and/or } \\
\text { Metra rail). }\end{array}$ & $\begin{array}{l}\text { Residents not currently well-served by } \\
\text { rail transit have a particular and pressing } \\
\text { need for rapid transit service within } \\
\text { walking distance of their homes. }\end{array}$ & $\begin{array}{l}\text { - Provide more transportation choices. } \\
\text { - Promote equitable, affordable } \\
\text { housing. } \\
\text { - Support existing communities. }\end{array}$ \\
\hline $\begin{array}{l}\text { Transportation } \\
\text { Costs }\end{array}$ & $\begin{array}{l}\text { Average household transportation } \\
\text { costs as a percentage of household } \\
\text { income (provided by the Center for } \\
\text { Neighborhood Technology) within } 0.5 \\
\text { miles }(0.8 \mathrm{~km} \text { ) of street segments. }\end{array}$ & $\begin{array}{l}\text { BRT can help make overall housing } \\
\text { costs more affordable by reducing the } \\
\text { transportation costs associated with } \\
\text { housing location. }\end{array}$ & $\begin{array}{l}\text { - Provide more transportation choices. } \\
\text { - Promote equitable, affordable } \\
\text { housing. } \\
\text { - Support existing communities. }\end{array}$ \\
\hline
\end{tabular}

Each street segment for each criterion in the Livability Analysis was scored (to allow for comparable values) using the following percent-rank equation:

$$
\text { Percent Rank }=\frac{(\text { Absolute Rank of a Street Segment }-1)}{(\text { Number of Street Segments }-1)}
$$

Individual Scoring: For each criterion, a 0.5 -mile $(0.8 \mathrm{~km})$-considered a reasonable walking distance by Nabors et al. (2008) — area around each street segment was spatially joined to each respective study measure. This was expressed as a point or polygon GIS shapefile. The Existing Transit Ridership and Existing Transit Travel Time criteria used a 0.25-mile $(0.4 \mathrm{~km})$ buffer and a 0.125 -mile $(0.2 \mathrm{~km})$ buffer, respectively, to control for more localized impacts. For each street segment, criteria were quantified by summing or averaging each study measure, as specified in Table 1. The percent rank function was used to score each street segment based on the summation or average of each metric relative to all other street segments.

Overall Scoring: The overall score, expressed as a percentage, was a composite of the weighted individual scores of each criterion. Weighting assigned importance to a criterion relative to all other criteria. The drawback of subjective weighting was considered to be offset by the benefit of expressing qualitative public policy goals and initiatives.

Each criterion was classified into four general scoring groups: 1) access to important trip generators, 2) transit performance, 3) transit equity, and 4) infill development potential. Criteria were weighted equally within each scoring group. 
The "access to important trip generators" scoring group included Employment/Job Access, Population, and all the "connectivity" criteria. This group echoed the FTA's recommendation to plan a BRT network that "connects disparate major generators of travel" (Panero et al. 2012,14). Project sponsors of some existing BRT systems in the United States felt that BRT "provided new or improved connections between regional employment and activity centers," a rationale for focusing BRT development in areas of high activity (Governmental Accountability Office 2012, 38).

The Existing Transit Ridership and Existing Transit Travel Time criteria represented the "transit performance" group. Given the relative importance of existing transit service to a BRT system, it was considered reasonable to give the Existing Transit Ridership and Existing Transit Travel Time criteria among the highest weightings. In evaluating project justification for major capital investment grants (49 U.S.C. $\$ 5309(\mathrm{~d})(3)(\mathrm{H})(2008)$ ) and New Fixed Guideway Grants (49 U.S.C. \$5309(d)(2)(B)(ii) (2012)), USDOT was required to evaluate current transit ridership in the transportation corridor.

"Transit equity" comprised the Population 0.5 Miles or More from Rail and Transportation Costs criteria. The Population not Served by Rail and Transportation Costs criteria shared the highest scoring with the transit performance measures to emphasize equity in transit distribution. This group also conformed to grant requirements under 49 U.S.C. $\$ 5309$ (d)(2)(A)(iv) (2012) requirement that projects are "supported by policies and land use patterns that promote public transportation...." (similar SAFETEA-LU language under 49 U.S.C. $\$ 5309$ (d)(2)(B) (2008)).

Deng and Nelson (2011) and the Government Accountability Office (2012) suggested growing evidence for a positive BRT impact on land value. "Infill development potential" at 3 percent of the overall score of each street segment was represented only by its namesake criterion because it could not be reasonably categorized elsewhere.

The remaining 97 percent of the overall score of each street segment was divided between the three remaining scoring groups (i.e., each group received $32.33 \%$ of the score).

After calculating the overall score of each street segment, the street segments were divided into "weak scoring" and "strong scoring" categories. The division between the categories was the median value of the overall score.

All street segments in the weak scoring category were removed from the analysis unless those street segments were flanked by an equal length of strong scoring segments (for the purpose of including isolated weak sections). The remaining routes were passed into Phase III.

\section{Phase III: Route Analysis}

The Route Analysis removed routes that did not have the potential to make connections to existing fixed guideway transit and reintroduced corridors that improved transit connectivity.

To be considered connected with existing transit, the BRT routes had to be located within 330 feet $(100.6 \mathrm{~m})$ of a Metra or CTA rail station. The 330-foot $(100.6 \mathrm{~m})$ buffer was con- 
sidered a reasonable, uncontrolled transfer distance between two fixed guideway transit lines.

The reintroduction or modification of routes was a qualitative approach driven by the desire to increase transit connectivity between existing transit and the BRT routes. Specific rationale behind the inclusion or exclusion of specific routes is described in the Results section.

\section{Phase IV: Travel Demand Analysis}

The purpose of this phase was to examine the potential transportation impact of a hypothetical BRT system based on the routes passing Phase III. Resource constraints did not allow modeling of individual routes or projections of future conditions; however, TCRP recommends that "BRT lines should be planned as an interconnected system" (Kittelson \& Associates 2007, S-2).

Potential BRT routes were modeled using the Chicago Metropolitan Agency for Planning (CMAP) "trip-based" travel demand model (stored and manipulated using INRO's Emme 3). The assumptions used in the model, but not the methodology behind the model (i.e., CMAP's manipulation of input data provided by the authors of this study), is discussed in this section.

CMAP provided modeling outputs for three scenarios: No Build, BRT with a 50 percent reduction in local bus service, and BRT with no local bus service. For both the BRT scenarios, two lanes (one in each direction) of existing travel lanes were removed for use as BRT-only lanes.

Assumptions on the average speed and headway of the BRT system were derived from research by Levinson et al. (2003b) and Kittelson \& Associates (2007). Average speed was assumed to be a conservative $15 \mathrm{mph}(24.2 \mathrm{~km} / \mathrm{h})$, accounting for a 30-second dwell time at each stop. The headway was set at five minutes based on a preference for high peak period performance.

The BRT stopping pattern was based on spacing recommendations from Levinson et al. (2003b) and Kittelson \& Associates (2007). Stops were established approximately every 0.5 mile $(0.8 \mathrm{~km})$, generally stopping at the major arterials in Chicago. Stops also were established at every Metra or CTA rail station regardless of whether this created a stopping frequency of less than 0.5 mile $(0.8 \mathrm{~km})$. Connections to the local bus network only occurred where BRT stations and the local bus system overlapped.

Automobile non-work trips were modeled during the midday period. Automobile work trips, transit work trips, and transit non-work trips were modeled during the morning peak period. 


\section{Results}

\section{Phase I: Preliminary Route Screening}

A total of 10 circulators and 22 special routes were eliminated, and 2 pairs of routes were consolidated. There were 121 routes that passed Phase I.

\section{Phase II: Segment Analysis Results}

The routes passing Phase I were converted into 11,891 street segments and then used in the Segment Analysis. There were 2,084 street segments and 23 series of street segments that collectively satisfied the 86 -foot $(26.2 \mathrm{~m}$ ) minimum, 3-mile ( $4.8 \mathrm{~km})$ length minimum, and 97 -foot $(29.6 \mathrm{~m})$ station requirements. These street segments were used in the Livability Analysis.The results of the overall score of the Livability Analysis for each criterion are shown in Figure 3.

FIGURE 3.

Map of routes passing

Phase II

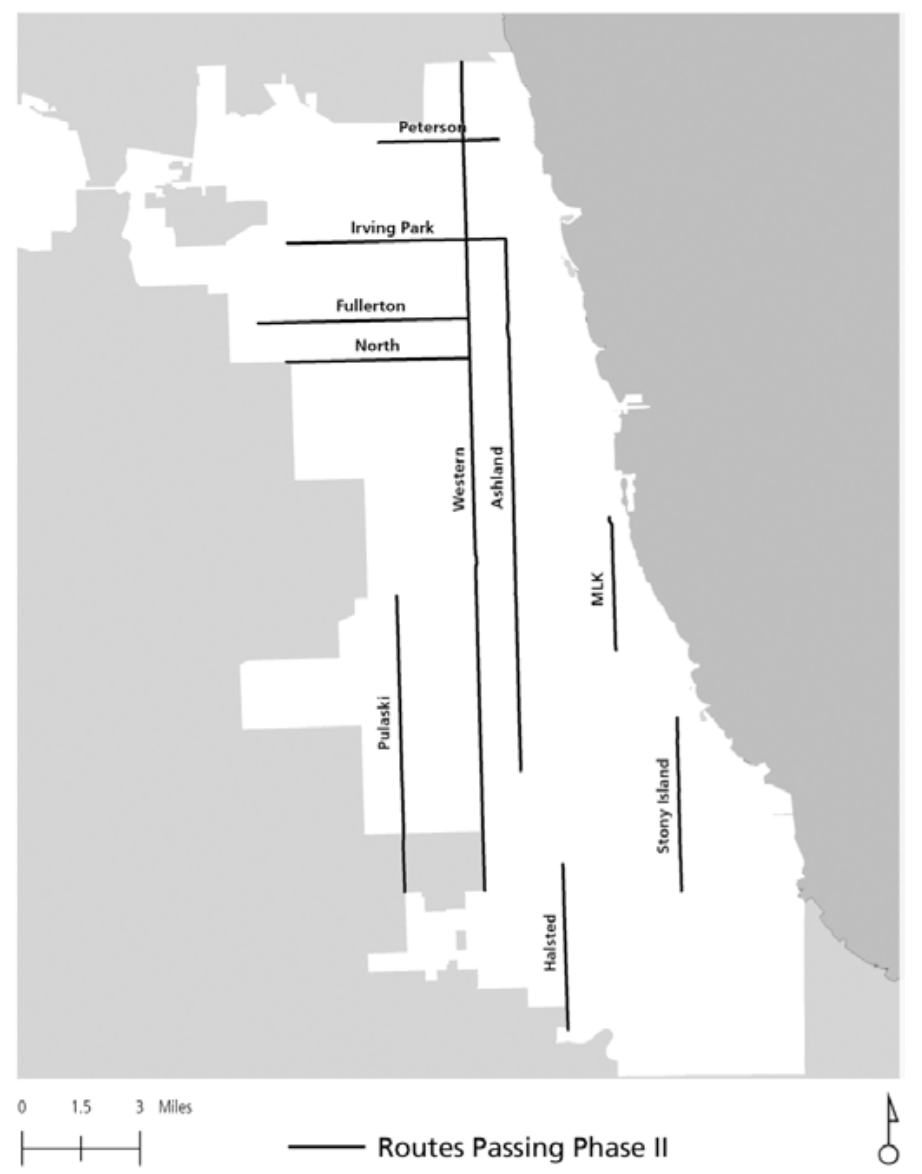

\section{Phase III: Route Analysis Results}

Two potential routes, North Avenue and Peterson Avenue, were removed because they did not connect to existing transit. Seven routes were reintroduced or altered from their previous alignments. These routes and a rationale for their reintroduction or alteration are included in Table 2. These routes were joined by Western, Irving Park, and Pulaski/ Crawford, which did not require revision. The alignments of routes passing Phase III are shown in Figure 4. 
TABLE 2.

Rationale for Reintroduction

of Routes in Phase III

\begin{tabular}{|c|c|c|}
\hline Route & Action Taken & Rationale for Reintroduction/Alteration \\
\hline $\begin{array}{l}\text { Fullerton/ } \\
\text { Grand }\end{array}$ & $\begin{array}{l}\text { Extended north to North 75th } \\
\text { Court, Elmwood Park, IL }\end{array}$ & - Connectivity to the Elmwood Park Metra Station \\
\hline Garfield & Reintroduced & $\begin{array}{l}\text { - Connectivity to the Garfield station of the CTA Red } \\
\text { and Green "L" lines } \\
\text { - Access to Washington Park and University of Chicago } \\
\text { (university and major medical facility) }\end{array}$ \\
\hline 95th & $\begin{array}{l}\text { Reintroduced and extended } \\
\text { north to South Cicero Avenue, } \\
\text { Oak Lawn, IL }\end{array}$ & $\begin{array}{l}\text { - Connection of } 6 \text { potential BRT routes } \\
\text { - Connectivity of } 4 \text { transit lines (Metra Rock Island } \\
\text { Branch, Metra Rock Island Main, Metra Electric, and } \\
\text { the CTA "L" Red Line) }\end{array}$ \\
\hline Cicero & $\begin{array}{l}\text { Reintroduced, extended north } \\
\text { to West 21st Place and south } \\
\text { to West 95th Street }\end{array}$ & $\begin{array}{l}\text { - Connectivity between Midway Airport and the western } \\
\text { most termini of the CTA Pink and Orange "L" lines } \\
\text { - Connectivity to the potential 95th BRT route }\end{array}$ \\
\hline Ashland & $\begin{array}{l}\text { Extended south to West 95th } \\
\text { Street }\end{array}$ & - Connectivity to the potential 95th BRT route \\
\hline Halsted & $\begin{array}{l}\text { Extended north to South } \\
\text { Vincennes }\end{array}$ & - Connectivity to the Metra Gresham Station \\
\hline $\begin{array}{l}\text { King/ } \\
\text { Stony } \\
\text { Island }\end{array}$ & Reconfigured (see Figure 4) & $\begin{array}{l}\text { - Access to McCormick Place Convention Center, } \\
\text { Washington Park, and University of Chicago } \\
\text { - Connectivity to the CTA Red and Green "L" lines and } \\
\text { the Metra electric line in } 2 \text { locations }\end{array}$ \\
\hline
\end{tabular}

FIGURE 4.

Map of routes passing

Phase III

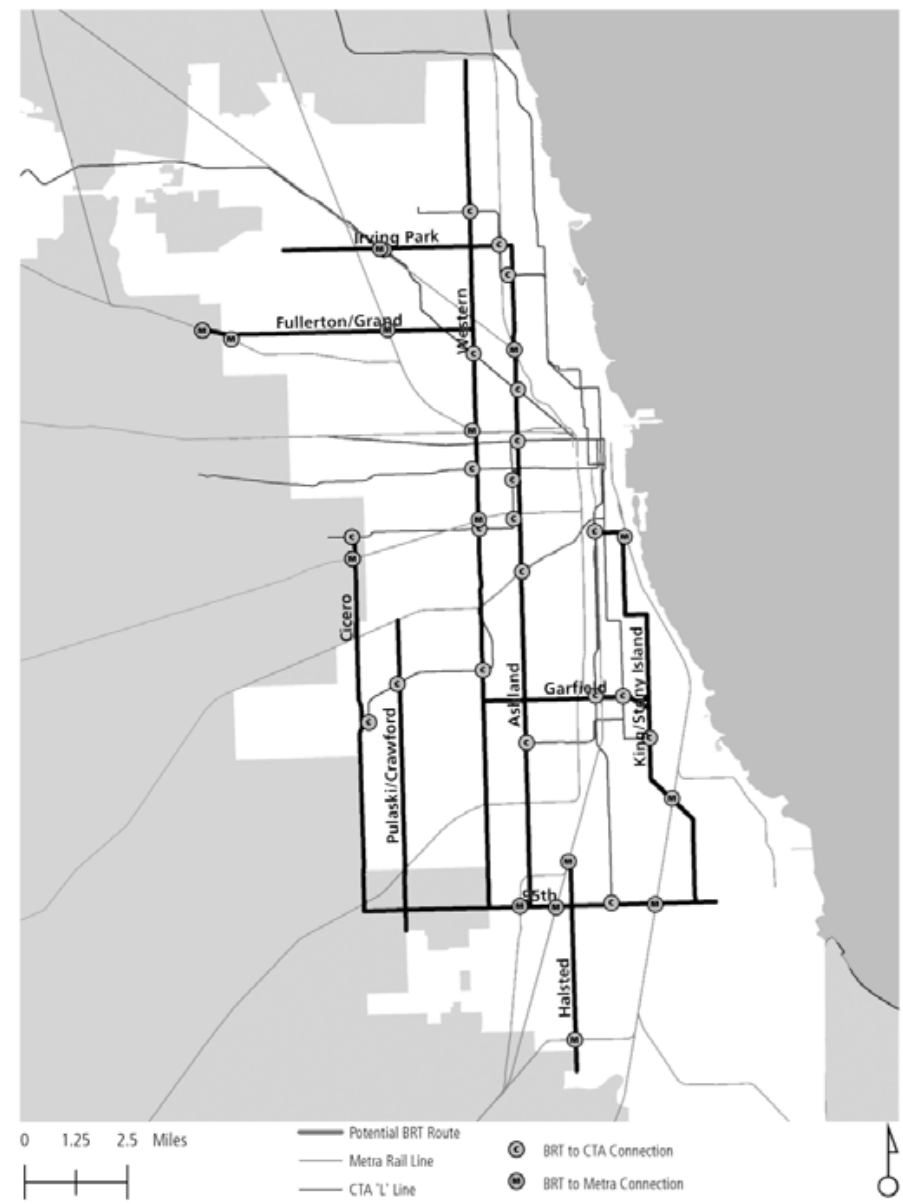




\section{Phase IV: Travel Demand Analysis Results}

CMAP staff prduced modeling results for all three scenarios. The results of the two BRT scenarios were almost identical given the demand model constraints; therefore, the results of the BRT/Reduced scenario will not be discussed.

\section{Person Trips}

There were approximately 2,423,000 daily person trips (transit and automobile) beginning and ending within the BRT Corridor (defined by traffic analysis zones adjacent to the 10 $B R T$ routes) modeled in the No Build scenario. The BRT scenario had higher results within the BRT Corridor at 2,457,000 person trips, a 33,000 person trip (1.4\%) increase over the No Build scenario.

\section{Transit Trips}

There were 40,000 (13.8\%) more transit trips beginning and ending within the BRT Corridor than in the No Build scenario. The total number of transit trips originating in the BRT Corridor increased by 51,000 trips (6.8\%). The total number of transit trips ending in the BRT Corridor increased by 47,000 trips (10.6\%).

\section{Transit Mode Share}

Transit mode share increased from 12.0 to 13.5 percent for trips beginning and ending within the BRT Corridor. Transit mode share increased from 14.7 to 15.8 percent for trips that either began or ended within the BRT Corridor.

\section{Vehicle Impacts}

Vehicles miles traveled (VMT) within the BRT Corridor decreased by 468 miles (753.1 km), a 2 percent decrease. Congested VMT increased by 953 miles $(1,533.7 \mathrm{~km})$, a 16 percent increase. Vehicle hours traveled within the BRT Corridor also increased by 62 hours, a 4 percent increase. Average vehicle speed within the BRT Corridor decreased by $1 \mathrm{mph}$ (1.6 $\mathrm{km} / \mathrm{h})$, to $16 \mathrm{mph}(25.7 \mathrm{~km} / \mathrm{h})$.

\section{Discussion and Recommendations}

The 10 routes emerging from Phase III were selected based on whether they 1) were practical, 2) best complemented existing livability conditions, and 3) would improve current transit connectivity.

The Right-of-Way Constructability Analysis in Phase II identified where a BRT route potentially could be constructed given the selected ROW constraints. Streets removed in this part of the analysis possibly could accommodate BRT if other street components (i.e., bike lanes, parkways, etc.) were removed or reduced in width; however, Complete Streets ideology necessitated the inclusion of sufficient ROW not only for the BRT system but also for other users of the public space. Exceptions to ROW requirements were made for the Cicero and King/Stony BRT routes for network integration purposes. In these instances, the benefit of better transit connections was considered to outweigh the loss of other ROW uses.

The importance of the Right-of-Way Constructability Analysis does not wholly undermine the intent of this paper to integrate the Livability Principles. The purpose of the 
study was to include the Livability Principles in selecting the final routes, not to use the Livability Principles as the only consideration. It is hoped that further research will replicate and refine the Livability Analysis method.

Although the modeling results of the 10 potential BRT routes may appear to be relatively insignificant, three key considerations should be given to the results. First, CMAP's demand model was not designed for the purpose of assessing a BRT system. Although the model had been modified, it was still limited. Second, the BRT model results reflected ridership as it would be in 2010. It did not consider the possibility of ridership increases over time. The model results did not describe ridership on the BRT routes themselves, but rather overall ridership within the BRT corridor. Further modifications to the network may be needed.

\section{Conclusion}

The study was innovative in that it went beyond traditional transportation metrics to attempt to screen the existing CTA bus network for the best first implementation of BRT routes in the Northeastern Illinois Region. In April 2013, CTA announced its plan to construct "gold-standard" BRT on Ashland Avenue (the same route recommended in this study) following a FTA-funded Livability Alternatives Analysis (Chicago Transit Authority 2012; Chicago Transit Authority 2013).

Application of the study methodology or variations thereof to other geographies and modes with less stringent physical constraints would provide beneficial insight into the validity of incorporating livability measures into transportation planning. The Chicago Metropolitan Agency for Planning (2012), for example, used a modified application of the Livability Analysis metrics-drawn explicitly from this study-for promoting extension of the CTA "L" Red Line. Additional changes to the Livability Analysis to conform to 49 U.S.C $\$ 5309$ (2012) instead of the Livability Principles directly may be beneficial.

\section{Acknowledgments}

The authors would like to acknowledge Emily Tapia-Lopez, Peter Skosey, and MarySue Barrett of the Metropolitan Planning Council and Claire Bozic and Kermit Weis of the Chicago Metropolitan Agency for Planning for their support and contribution to this report.

\section{References}

Center for Urban Transportation Research. 2004. Overview of bus rapid transit opportunities as part of an integrated multi-modal strategy to alleviate traffic congestion in Miami-Dade County. Tampa, FL: Center for Urban Transportation Research.

Chicago Metropolitan Agency for Planning. 2008. Preservation of parks and open lands strategy. Chicago, IL: Chicago Metropolitan Agency for Planning.

Chicago Metropolitan Agency for Planning. 2012. Improving access, increasing livability: The CTA Red Line South Extension technical report. Chicago, IL: Chicago Metropolitan Agency for Planning. http://www.cmap.illinois.gov/documents/20583/1278736/ 
Red_Line_technical_report_12-10-12/4fd4857b-a817-4959-af1f-19f02f61de1c, accessed September 9, 2013.

Chicago Transit Authority. 2008. Chicago will receive $\$ 153.1$ million grant to help relieve traffic congestion. http://www.transitchicago.com/news/default.aspx?Month=4\&Year $=2008 \&$ Category=\&Archive=y\&Articleld=189. accessed February 26, 2012.

Chicago Transit Authority. 2013. Ashland bus rapid transit. http://www.transitchicago. com/ashlandbrt/, accessed April 23, 2013.

Chicago Transit Authority. 2012. Western and Ashland Corridors bus rapid transit. http:// www.transitchicago.com/westernashlandbrt, accessed April 2, 2013.

City of Chicago. 2013. Rockefeller Foundation renews support for Chicago bus rapid transit.

http://www.cityofchicago.org/city/en/depts/cdot/provdrs/transit_facilities/ news/2013/jan/rockefeller_foundationrenewssupportforchicagobusrapidtransitdeve.html, accessed August 25, 2013.

Deng, Taotao, and John D. Nelson. 2011. Recent developments in bus rapid transit: A review of the literature. Transport Reviews 31(1): 69-96.

Hensher, David A., and Zheng Li. 2012. Ridership drivers of bus rapid transit. Transportation 39(6): 1209-1221.

Institute of Transportation \& Development Policy. 2013. The BRT standard 2013. New York, NY: Institute for Transportation \& Development Policy.

Institute of Transportation Engineers. 2010. An ITE recommened practice: Context sensitve solutions in designing major urban thoroughfares for walkable communities. Washington, DC: Institute of Transportation Engineers.

Kittelson \& Associates, Inc. 2007. Transit Cooperative Research Program Report 118. Washington, DC: Transportation Research Board of the National Academies.

Levinson, Herbert S., Samuel Zimmerman, Jennifer Clinger, Scott Rutherford, Rodney L. Smith, John Cracknell, and Richard Soberman. 2003a. Transit Cooperative Research Program Report 90, Bus Rapid Transit Volume 1: Case studies in bus rapid transit. Washington, DC: Transportation Research Board of the National Academies.

Levinson, Herbert S., Samuel Zimmerman, Jennifer Clinger, James Gast, Scott Rutherford, and Eric Bruhn. 2003b. Transit Cooperative Research Program Report 90, Bus Rapid Transit Volume 2: Implementation guidelines. Washington, DC: Transportation Research Board of the National Academies.

McNamara, lan G., Samuel L. Zimmerman, Theodore Orosz, Herbert S. Levinson, and David Sampson. 2006. Bus rapid transit in New York City: Corridor evaluation and screening. Transportation Research Record 1971: 3-13.

Panero, Marta, Hyeon-Shic Shin, Allen Zedrin, and Allen Zimmerman. 2012. Peer-to-peer information exchange on bus rapid transit (BRT) and bus priority best practices. Washington, DC: Federal Transit Administration. 
Partnership for Sustainable Communities. 2012. Three years of helping communities achieve their vision for growth and prosperity. Washington, DC: Partnership for Sustainable Communities. http://www.sustainablecommunities.gov/pdf/HUD-partnership-07-19-2013.pdf, accessed September 1, 2013.

Nabors, Dan, Robert Schneider, Dalia Leven, Kimberley Lieberman, and Colleen Mitchell. 2008. Pedestrian Safety Guide for Transit Agencies. Washington, DC: Federal Highway Administration.

U.S. Environmental Protection Agency. 2009. HUD, DOT and EPA Partnership: Sustainable communities. http://www.epa.gov/smartgrowth/pdf/dot-hud-epa-partnershipagreement.pdf, accessed January 15, 2012.

U.S. Government Accountability Office. 2012. Bus rapid transit-Projects improve transit service and can contribute to economic development. Washington, DC: U.S. Government Accountability Office. http://www.gao.gov/assets/600/592973.pdf, accessed August 28, 2013.

Weinstock, Annie, Walter Hook, Michael Replogle, and Ramon Cruz. 2011. Recapturing global leadeship in bus rapid transit: A survey of select U.S. Cities. New York, NY: Institute for Transportation and Development Policy.

Wright, Lloyd, and Walter Hook, eds. 2007. Bus Rapid Transit Planning Guide. New York, NY: Institute for Transportation \& Development Policy.

\section{About the Authors}

JOSHUA ANDERSON (josha@uchicago.edu) is the Assistant Director of Neighborhood and University Development at the University of Chicago's Office of Civic Engagement where he has dual responsibilities in neighborhood planning and municipal outreach. He advances community and economic development initiatives in the surrounding neighborhoods and coordinates University projects and campus planning with the City of Chicago and its sister agencies. He is the former vice-president of Transport Chicago, an organization that provides a forum for the exchange of knowledge in transportation research, policy, and practice via its annual conference. He previously worked for the Metropolitan Planning Council (MPC) as a consultant for their work on advancing BRT in the Chicago region.

JosH ElLIS (jellis@metroplanning.org) is a Program Director at the MPC. His focus is on advancing the MPC's environmental and economic goals through policy research, advocacy, and community engagement. He also manages the MPC's geospatial analysis of emerging environmental, economic, and demographic trends. He directs MPC's water resources programs and provides technical assistance through several regional partnerships, including the Northwest Water Planning Alliance. He co-authored Before the Wells Run Dry and now works with state, regional, and local leaders on strategies to sustainably manage Illinois' finite water resources. 